\title{
SYMBIOSIS OF ARTISTIC TRENDS IN CONTEMPORARY LITERATURE OF THE ARAB COUNTRIES OF THE PERSIAN GULF
}

\author{
Shakhlo Irgashbaevna Akhmedova
}

Candidate Of Philological Sciences, Tashkent State University Of Oriental Studies, Uzbekistan

\section{ABSTRACT}

The article deals with the accelerated development of fiction in the Arab countries of the Persian Gulf. It discusses questions fit into the "theory of accelerated development" of national literatures, received recognition in the contemporary literary criticism. The article notes that the fiction of these countries in their abrupt development has evolved from the medieval literary traditions to meet the taste of works of the modern reader for the short time. The development of modern prose in the Arab countries of the Persian Gulf is seen on the background of tremendous changes that took place in the socio-economic and cultural life of these countries in the second half of the twentieth century.

It is also noted that the presence of common features of formation of modern prose in these countries, there are differences in the level of artistic works maturity and volume of the created writings.

KEYWORDS: - The world literary process, contemporary prose, "Al-Khaleej" in Arabic literature, in the second half of the twentieth century, realism, romanticism, surrealism.

\section{INTRODUCTION}

The formation of modern literature in the Arab countries of the Persian Gulf took place in the second half of the twentieth century, several decades after the formation of modern literature in Egypt, Syria, Lebanon, Iraq, Tunisia and other culturally developed Arab countries. But its development proceeded so intensively that by the end of the twentieth century, the literature of the Arab countries of the Persian Gulf almost reached the level of literature of the above-mentioned Arab countries in the similarity of the manifestation of various artistic phenomena. The study of the literatures of the Arab countries of the Persian Gulf - the countries of al-Khaleej "Gulf", as the Arabs themselves call them, integrating at the present stage into the world literary process, acquires special scientific significance, since this issue is associated with a particular accelerated development of the literatures of the countries of the Arabian Peninsula.

\section{THE MAIN FINDINGS AND RESULTS}

If the literary renewal in Egypt, Lebanon, Syria and some Arab countries as a whole began in the second half of the 19th century, in the countries of the Arabian Peninsula this process was observed a whole century later, that is, in the second half of the 20th century, and in a short time the transition from medieval literary traditions to modern literature of a new type. Moreover, in its spasmodic development, part of al-Khaleej's literature in an extremely short time passed through the same 
CURRENT RESEARCH JOURNAL OF PHILOLOGICAL SCIENCES 2(9): 105-

109, September 2021

DOI: https://doi.org/10.37547/philological-crjps-02-09-23

ISSN 2767-3758

(C)2021 Master Journals

\section{Crossref do}

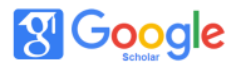

Accepted25 $5^{\text {th }}$ September, 2021 \& Published $30^{\text {th }}$ September, 2021

stages as modern developed Arabic literatures, and on the other hand, another part merged into the general Arab literary process, bypassing these stages. The specific path of development of the literatures of al-Khaleej contributed to the emergence of the "theory of accelerated development" [Suvorov 2011: 3].

Thus, the accelerated transition of Kuwait, Bahrain, Qatar, and other countries of the Persian Gulf to modern literature of a new type had a complex, contradictory, leap and bounds character. We can see the reason for this in the fact that modern culture in the Arab countries of the Persian Gulf developed against the background of a kind of socio-historical reality through which these countries passed in the twentieth century.

These countries, characterized by a backward way of life in the first decades of the twentieth century, in the second half, experienced very dramatic economic, social and political changes associated with the oil boom, which immediately affected the formation of a new artistic consciousness. Such turns were not observed in Egypt, Syria, Lebanon, where literary renewal took place more slowly and in stages. At the same time, in the countries of the Arabian Peninsula, the development of literature was uneven. The formation of modern literature in Kuwait, Bahrain, Yemen and Saudi Arabia began in the 40-50s of the twentieth century, when writers of the common Arab level had already appeared. But the process of updating literature in Qatar, Oman and the United Arab Emirates took place later, in the $60 \mathrm{~s}$ and $70 \mathrm{~s}$ of the twentieth century, and was primarily expressed in the desire to catch up with other Arab countries in terms of publishing activity.

In general, the rapid development of television, radio, press and other media in al-Khaleej countries led to the flourishing of journalism and journalism.
Circulation of newspapers and magazines exceeds tens and even hundreds of thousands of copies. Thus, the circulation of the Kuwaiti magazine "AlArabi", founded in 1960 and having at the beginning a circulation of 35,000 copies, and 1985 amounted to 350,000 copies, surpassing the circulation of all other Arab magazines [Otig 1986: 67]. The main task of the journal, which has been published so far, has been to popularize the achievements of human civilization in the field of science and culture, as well as to familiarize readers with the problems of national culture, including literature.

The Al-Kuwait magazine, founded in September 1982 , also had a great influence on the formation of readers' tastes. Both of these magazines had applications where works of Arab and foreign authors of a cultural and theoretical nature were published, for example, on the connection between art and philosophy, on the psychology of creativity, works on Arab social thought. The theatrical section includes dramatic works of various foreign authors translated into Arabic, from the ancient Greek ones, Sophocles and Aeschylus, to the modern ones, Olby and Maxwell Andersen, as well as works by prominent Arab playwrights [Khodzhaeva 2004: 24]. Exactly the same mission is performed by cultural and literary magazines in Bahrain, such as "Sawt al-Bahrain", "Al-Jamila", "Kitabat" and others. Similar magazines were published in other Arab countries of the Persian Gulf, Qatar, Oman, etc. Although they did not have such a large circulation as the aforementioned magazines, they also served as a cultural bridge that connected the societies of these countries with the rich Arab cultural heritage. At the same time, such magazines opened windows for the readers of al-Khalija to the wide world, introducing them to various countries and peoples, with the achievements of science and culture.

If we dwell on the peculiarities of the development of modern prose in the countries of al-Khaleej, we 
CURRENT RESEARCH JOURNAL OF PHILOLOGICAL SCIENCES 2(9): 105-

109, September 2021

DOI: https://doi.org/10.37547/philological-crjps-02-09-23

ISSN 2767-3758

(C)2021 Master Journals

\section{Crossref do}

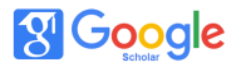

Accepted25 $5^{\text {th }}$ September, 2021 \& Published $30^{\text {th }}$ September, 2021

can observe the following picture. The prose of these countries expanded its possibilities primarily thanks to the literature of Egypt, Syria and Lebanon, which was facilitated by the common literary Arabic language, which made it easy to adopt the experience of prominent writers of those countries. Another feature is that Arab writers from the Gulf countries did not adapt the forms of medieval genres to express new content, but immediately switched to modern literary genres, just as they did not intensively search for new styles of presentation. The literature of Egypt and Syria had a century of experience in creating new Arabic literature. Periodicals, including art-critical works, received in large numbers from Egypt, Lebanon, Syria and other Arab countries, played a huge role in the formation of literary taste.

The writers of Kuwait and Bahrain in the 40-50s of the twentieth century, living in rather difficult socio-economic conditions, were closest to the ideas of the enlighteners of Egypt, Syria and Lebanon, since they saw the factor of their tasks in raising the consciousness and moral and moral foundations of society. "Oil money" sprinkled as a result of oil production has completely changed the life of the countries of the Arabian Peninsula. The material situation of the population has grown sharply. Thanks to the rush of the most advanced technical means into the country, the opportunity to get acquainted with the achievements of world civilization in all areas has expanded. As a result of the accelerated acquaintance and interaction with various literatures in the literature of these countries, there was observed the coexistence of several directions at the same time - from educational to modernist. If in the literature of Egypt, Syria and Lebanon the formation and development of each direction took several decades, then in the literature of Kuwait, Bahrain and Yemen there are phenomena when one direction, not fully formed, was replaced by another. In the literature of Qatar, Oman and the United Arab Emirates, educational literature did not develop at all, almost no genres were created that relate to educational literature, such as historical novels, philosophical and encyclopedic works. Their place was taken by social and everyday stories and novels. Sometimes didactics was noticed in these works, more romantic mood slipped through ("al ittijah al - vidaniya"). The emergence of a romantic mood was associated with drastic socio - economic changes in these countries, which caused feelings of nostalgia for disappearing traditions and a quiet life, disrupted as a result of radical changes in the turmoil of the construction boom and the breakdown of familiar social relations.

Simultaneously with these directions, a realistic style was also formed in social and everyday works, suggesting a truthful description of the life of the heroes. By this time, the developed literatures of Egypt, Syria and Lebanon were already dominated by various currents of a realistic direction and modernist tendencies were outlined. In the 50-60s of the twentieth century, the liberation from the colonialists and the establishment of independence in such Arab countries as Egypt, Syria, Lebanon, Iraq, Tunisia and Algeria led to the intensification of relations between the enlightened people of these countries, especially the writers, and the writers of the al-Khaleej countries.

The development of these relations was further facilitated by the transformation of publishing houses, radio and television into the field of general Arab news. For the writers of al - Khaleej countries, such famous Arab writers as Taha Hussein, Mahmoud Teymur, Tawfiq al - Hakim, Nagib Mahfuz, Yusuf Idris, Hanna Minna, Jubran Khalil Jubran, Tahir Wattar, Zunnun Ayub and others were considered "teachers". Their works have been carefully studied, followed often. Modern fictional prose genres - an essay, a story, a novel, a story - 
CURRENT RESEARCH JOURNAL OF PHILOLOGICAL SCIENCES 2(9): 105-

109, September 2021

DOI: https://doi.org/10.37547/philological-crjps-02-09-23

ISSN 2767-3758

(C2021 Master Journals

\section{Crossref do}

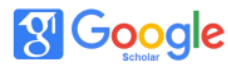

Accepted25th September, 2021 \& Published $30^{\text {th }}$ September, 2021

were perceived through the works of these writers. Many Kuwaiti and Bahraini writers studied in Egypt, Syria, and Lebanon and moved around in the literary environment of these countries. But we are mistaken if we say that the writers of Al - Khalijah completely imitated the Egyptian, Syrian and Lebanese mentors. Their works are distinguished by a national peculiarity due to the originality of the mentality, culture, the way of life of the peoples of these countries, the social and political environment and the originality of the language used in the works, as well as the dialect, which she also sometimes used.

In the genre relation in the prose of these countries until 70, almost no novels were created and later, unlike Saudi and Yemeni prose, where the novel was sufficiently developed, the short story was successfully developed in the countries of al-Khaleej as the most favorite genre of prose.

Kuwaiti, Bahraini and Qatari writers who entered the literary path in the 70s Suleiman al-Shati, Abd al-Aziz al-Sariy, Sulaiman al-Huleifi, Laylo al-Usman, Surayya al-Baksami, Ismail Fahd Is-Rajabalid ar, Munna ash-Shafeh, Amina Shaib, Bizza al-Batinyi published several collections of short stories. Their stories are well known in the Arab world, and have been translated into Russian, English, French and other European languages. Another feature of the modern prose of the al-Khalijah countries is the widespread development of female creativity. For example, in Kuwait, among the talented young people who entered the literary path in the 70s of the last century, there were quite a few girls. Out of them, such venerable masters of words as Leyla alUsman, Suraya al-Baksami, Fatima Yusuf Ali, from Bahrain Munis Faris, from Qatar Sary Ali Miza, Sahim Said al-Mari, Nuf Abd al-Hakim Nasir and others grew up.

The rise of realism in al-Khaleej's prose did not take an easy path. Although the writers intensively familiarized themselves with examples of realistic literature, the improvement of the realistic direction in these countries was somewhat hampered by internal socio-political, spiritual and cultural factors. First, the censorship of a restriction or prohibition extended to religious, political topics themselves, to relations between a man and a woman that went beyond the Shariah. Secondly, the authors themselves have not yet sufficiently developed the skills of communication and typification, bypassing a specific environment, in addition, their consciousness has not yet been freed from the influence of the canyons of traditionalism.

The realism in the literatures of al-Khaleej had not yet had time to take shape in a mature direction, when in the mid-70s, under the influence of European literature, modernist tendencies began to appear under the influence of European literature. As a result, there are elements of absurd literature and surrealism in the stories. Young authors, having barely familiarized themselves with foreign literature, began to use modern writing techniques and techniques characteristic of modernism: such as stream of consciousness, associative thinking, collage, fragmentation, etc.

\section{Conclusion}

In the 80s of the twentieth century, the literature of al-Khaleej was somewhat improved in it, works appeared that were able to show both the external and internal world of a person, based on psychological analysis. Thus, al-Khalijah in the prose of the Arab countries of 60-90 years of the twentieth century; we can observe the simultaneous coexistence of modernism, romanticism ("al-ittijah al-vision") and realism, there is also a tendency towards didactics characteristic of educational literature.

Thus, the literatures of al-Khaleej joined the general 
CURRENT RESEARCH JOURNAL OF PHILOLOGICAL SCIENCES 2(9): 105-

109, September 2021

DOI: https://doi.org/10.37547/philological-crjps-02-09-23

ISSN 2767-3758

(C2021 Master Journals

Crossref doi

Accepted25 $5^{\text {th }}$ September, 2021 \& Published $30^{\text {th }}$ September, 2021

Arab literary process, and the works of the writers of these countries crossed their own borders and the borders of the Arab world. At the same time, the literatures of the al-Khaleej countries are included in the world literary process and are subject to the same influences of modern trends and trends that are included in this process at the present stage, while maintaining their originality and national identity.

\section{REFERENCES}

1. Suvorov M.N. (2011) Fiction of Yemen (On the Problem of the Accelerated Development of the Literatures of the Countries of Arabia). Abstract of thesis. Doctor. Diss. - Saint Petersburg. (Суворов М.Н. Художественная проза Йемена (К проблеме ускоренного развития литератур стран Аравии). Автореф. док...дисс...Санкт - Петербург, 2011.)

2. Nastig R. (1986) Kuwait. Literary and social life of the Arab countries. - Moscow. (Настиг P. Кувейт. Литературно-общественное жизнь арабских стран. М.1986.)

3. Khodzhaeva R.U. (2004) Literature brings peoples closer together. On the article "The current state and prospects for the development of bilateral interstate relations of the Republic of Uzbekistan and the State of Kuwait" Conference materials. - Tashkent. (Ходжаева P.У. Литература сближает народы. В сб. «Современное состояние и перспективы развития двухсторонних межгосударственных отношений Республики Узбекистан и Государства Кувейт». Материалы конференции. Т., 2004.)

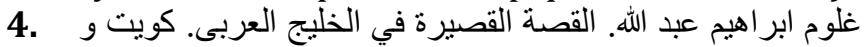

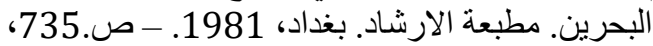

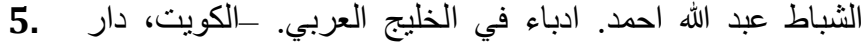
الوطنية الجديدة للنشر و التوزيع الرياض، 1986.

6. Kirpichenko V.N. (2002) New Arabic literature. Study of oriental literatures. Russia. - Moscow.
Eastern Literature. (Кирпиченко В.Н. Новая арабская литература // Изучение восточных литератур. Россия. - М., Восточная литература, 2002.)

7. Michalak-Pikulska, Barbara. Modern poetry and prose of Oman. 1970-2000. Kraków, 2002. - 440 pp.

8. Michalak-Pikulska B.The contemporary Kuwaiti short story in peace time and war. Krakow 1998. P. 49..

9. Ramsay G. The past and present Aspects of intertextuality in modern literature in the Gulf // intertextuality in modern Arabic literature since 1967/Durham Durham University 2006.P.374 